\title{
Salary Satisfaction and Turnover Intentions among the Teaching Staff in Public Universities in Kenya
}

\author{
Sarah Likoko, Jane Barasa \\ Department of Educational Planning and Management, Kibabii University, Kenya
}

\begin{abstract}
The purpose of this study was to investigate the influence of salary satisfaction on turnover intentions among the teaching staff in public Universities in Kenya.The study employed ex post facto research design to test the statistical relationships between the variables. Simple random sampling was used to select 376 teaching staff members. Data was collected using a structured questionnaire (likert type scale 1-5). Data was analyzed using correlation and simple linear regression analysis. The study concluded that salary satisfaction had a significant negative influence on the turnover intentions amongst the teaching staff in Kenyan Public Universities
\end{abstract}

Keywords: Salary Satisfaction, Teaching Staff, Turnover Intentions

\section{INTRODUCTION}

$\mathrm{H}$ igh employee turnover have a negative effect on the sustained growth and development of any organisation (Adedamola, 2016).Some studies showed that in every $10 \%$ increasing of turnover rate would cause decreasing of organization outcome (Park \&Shaw, 2013). It causes organizations to consume more energy in maintaining the stability of the organization input and output (A'yuninnisa $\&$ Saptoto, 2015).Therefore, once an organization has captured skilled employees, the return on investment requires closing the back door to prevent them from walking out (Tymon et al., 2011).

However, Spherion (2013) quoted that 49 percent of employers considered remuneration as a vital concern in retaining their employees, while 69 percent of employees identified pay as crucial factor. In addition, Saira et al., (2014) notes that employees' willingness to stay on the job largely depends on salary they receive from employers. Hasibuan, Mariatin, and Ananda (2019) also indicate that unsatisfactory remuneration practices lead to increase in turnover intentions among workers. Therefore, salary satisfaction is of primary concern to both employers and employees

\subsection{Research Hypothesis}

The following hypothesis was constituted:

Ho: Salary satisfaction has no statistically significant influence on turnover intentions among the teaching staff in public Universities in Kenya.

\section{LITERATURE REVIEW}

Mabaso \& Bongani (2017) noted that a remuneration package is one of the most important factors that influence people to take up employment and stay with organisations. Systematic reviews of the previous studies indicate that uncompetitive salaries do have a negative impact on retention (Schmiedeknecht et al., 2015; De Bruyn, 2014; George et al., 2013). In addition, Demaki (2012) had similar sentiments; that money does not only meet material needs of workers but also gives them psychological satisfaction which leads to job retention. Moreover, Mustapha (2013) pointed out that remuneration system plays an important role in determining an employee's level of job satisfaction. If individuals believe they are not compensated well, a state of emotional dissatisfaction will develop. This emotional disagreement will accrue over time and make the employee want to leave the organization in search of greener pasture (Olawale \& Olanrewaju, 2016). However, the current study sought to establish if there exist similar situations among the teaching staff in public Universities in Kenya

More recently, Ezeh et al.,(2017) carried out a study on pay satisfaction, job satisfaction and gender as correlates of turnover intention among Federal Civil Servants in Awka Metropolis of Anambra State, South-East, Nigeria.Three hundred and seventy seven (377) participants comprised of 176 males and 206 females. Pearson's correlation and Independent sample t-test were adopted to analyze the data. Results revealed that pay satisfaction had no significant relationship with turnover intention. From the study, Ezeh et al., (2017) focused on non-teaching staff; hence this limits generalizability of the findings especially to the teaching staff in Kenyan public Universities where the political and geographical settings are different from Nigeria.

According to Raza et al., (2017) who found a significant and negative relationship between pay satisfaction and turnover intention among employees of both public and private banks in Vehari, Pakistan. The study collected the data from a sample of 100 bank employees both public and private banks in Vehari. The shortcomings in Raza et al., (2017) study was that the findings were limited to the banks of one city in Pakistan, making it difficult for the researcher to generalize the results to the teaching staff in public Universities in Kenya. The current study therefore was set to address the gap. 
Kinyili (2015) explored the role of human resources management practices on the retention of staff in public health institutions in Machakos County. The study adopted a mixed method research design. Stratified, random and purposive sampling was used to select a total of 263 respondents from the various strata identified. Both interviews and selfadministered questionnaires were used on data collection. The results indicated that there is a significant relationship between remuneration and retention $(F(9.847, d f=1$, and $p<0.05)$. However, the generalization of the research findings should be done with a lot of caution since Kinyili (2015) focused on public health workers who operate under different work environment compared to teachers in public sector.

Still in most recent time, Mbane (2017) carried out a study on employee retention in selected hotels in Cape Town, South Africa. This study aimed at investigating employee retention variables at hotels in Cape Town, focusing on three to five star graded establishments. Structured questionnaire surveys, using non-probability sampling, were applied in the form of a convenience approach. Hotels willing to participate in the study were selected, as Cape Town has a large population of hotels. Data for this study was collected over a period of ten months. A bivariate analysis was applied in this research in the form of correlation and Chi-square tests, after descriptive statistics were done. This study found a very strong correlation between fair remuneration and employee retention. Employees who perceived themselves as fairly compensated in the hotel wanted to work long-term in the hotel. However the results could not be generalized since some hotels in Cape Town rejected taking part in the research. Therefore, a nonprobability sampling, as mentioned earlier, was used, yet does not give an equal chance to every employee to take part in the study. This was a limitation to Mbane (2017) study that the current study sought to address.

The works of Sattar \&Ahmad (2014) also observed that salary was a major aspect of human resource practices in a study of both private and public banks in Bahawalpur district in Pakistan. The population of the study included employees of all 116 branches of banks of Bahawalpur district. A sample of 150 private and public banks of Bahawalpur was selected for the survey. Data was analysed by using cronbach's alpha, correlation and regression in SPSS software. Random sampling technique was used. Instruments used for data collection was a questionnaire on 5-point likert scale from strongly agree to strongly disagree, where point-1 indicate strongly agree, 2 agree, 3 neutral, 4 disagree , 5 strongly disagree (Abdallah et al.,2017). They submitted that employees experienced little remuneration growth and benefits. The results indicated that remuneration have less influence on employees turnover. However, Pakistan is one of the least developed countries, where 22.3 percent of people live below the poverty line (Arif \& Farooq, 2012). In this regard, generalizability of the research findings should be done with a lot of caution

\section{METHODOLOGY}

This study employed ex post facto research design. The study sample was 376 teaching staff from public Universities in Kenya. A structured questionnaire was used in collecting data. A questionnaire was preferred because it is suitable for statistical analysis (Kratina et al., 2015). The researchers considered simple random sampling for choosing the respondents.

\section{RESULTS AND DISCUSSION}

\subsection{Salary Satisfaction and Turnover Intentions among the Teaching Staff in Public Universities in Kenya}

To measure the level of salary satisfaction, a multi-item 5point likert scale was used. Respondents were asked to rate on the scale their level of agreement with the various items indicating level of satisfaction. Their responses were analyzed using frequency counts and weighted averages and are shown in Table 1.

Table 1: Level of Satisfaction with Remuneration Practices

\begin{tabular}{|c|c|c|c|c|c|c|c|}
\hline $\begin{array}{c}\text { Remuneration } \\
\text { Practices }\end{array}$ & $\mathrm{SA}$ & $\mathrm{A}$ & $\mathrm{U}$ & $\mathrm{D}$ & $\mathrm{SD}$ & $\sum \boldsymbol{f}_{\boldsymbol{i}}$ & $\frac{\sum \boldsymbol{f}_{\boldsymbol{i}} \boldsymbol{w}_{\boldsymbol{i}}}{\sum \boldsymbol{f}_{\boldsymbol{i}}}$ \\
\hline $\begin{array}{c}\text { I am satisfied } \\
\text { with my current } \\
\text { pay package }\end{array}$ & 8 & 47 & 45 & 141 & 135 & 376 & 2.07 \\
\hline $\begin{array}{c}\text { My monthly } \\
\text { salary is } \\
\text { sufficient to } \\
\text { satisfy all } \\
\text { important } \\
\text { expenses }\end{array}$ & 6 & 35 & 42 & 159 & 134 & 376 & 1.99 \\
\hline $\begin{array}{c}\text { I am underpaid } \\
\text { in relation to } \\
\text { my duties }\end{array}$ & 35 & 102 & 82 & 36 & 21 & 376 & 3.78 \\
\hline $\begin{array}{c}\text { Salary raises } \\
\text { are regular }\end{array}$ & 10 & 65 & 59 & 164 & 78 & 376 & 2.38 \\
\hline
\end{tabular}

Source: Field Data(2020)

To answer the question on whether the teaching staff were satisfied with their current pay packages, 276 respondents representing $73.4 \%$ disagreed (score 1 and 2 on the scale) while 55 representing $14.6 \%$ agreed (score 4 and 5 on the scale). With a weighted mean of 2.07 which represent 'disagree', the results indicate that the teaching staff in public Universities in Kenya was not satisfied with the pay packages they receive.

In response to the assertion that the monthly salary was sufficient and satisfied all important expenses, 293 respondents representing $77.9 \%$ disagreed (score 1 and 2 on the scale) while 41 representing $10.9 \%$ agreed (score 4 and 5 on the scale). With a weighted mean of 1.99 which represents 'disagree', the results indicate that the teaching staff in public Universities in Kenya disagree that their monthly salary was sufficient to satisfy all important expenses.

In this question the researcher sought to get responses on whether they are underpaid in relation to their duties, 57 
respondents representing $15.2 \%$ disagreed (score 1 and 2 on the scale) while 237 representing $63.0 \%$ agreed (score 4 and 5 on the scale). With a weighted mean of 3.78 which represent 'agree', the results indicate that the teaching staff in public Universities in Kenya felt that they were underpaid in relation to their duties.

Lastly, the assertion to whether salary increments were regular, 242 respondents representing $64.4 \%$ disagreed (score 1 and 2 on the scale) while 75 representing $19.9 \%$ agreed (score 4 and 5 on the scale). With a weighted mean of 2.38 which represent 'disagree', the results indicate that the teaching staff in public Universities in Kenya does not receive regular salary increments.

Table 2: Descriptive Statistics of Salary Satisfaction Indices

\begin{tabular}{|c|c|c|c|c|c|}
\hline & N & Min. & Max. & Mean & $\begin{array}{c}\text { Std. } \\
\text { Dev }\end{array}$ \\
\hline $\begin{array}{c}\text { Salary } \\
\text { satisfaction }\end{array}$ & 376 & 4.00 & 20.00 & 20.7367 & 6.59594 \\
\hline
\end{tabular}

Results presented in Table 2 shows that salary satisfaction had a mean of 20.7367 with the other scores deviating from the mean by 6.59594 . The mean indicates that the teaching staff in public Universities in Kenya were not satisfied with the salary.

\subsection{Correlation between Salary Satisfaction and Turnover Intentions}

The Pearson's correlation coefficient was used to measure the nature and strength of the relationship between salary satisfaction and turnover intentions among the teaching staff in public Universities in Kenya. The results are reported in Table 3.

Table 3: Correlations between Salary Satisfaction and Turnover Intentions

\begin{tabular}{|c|c|c|c|}
\hline Salary Turnover & & & \\
\hline Index & Intent & & \\
\hline Salary & $\begin{array}{c}\text { Pearson } \\
\text { Correlation }\end{array}$ & 1 & \\
\hline Sig. (2-tailed) & & & \\
\hline $\mathrm{N}$ & 376 & & \\
\hline Turnover & & & 1 \\
\hline Intent & $\begin{array}{c}\text { Pearson } \\
\text { Correlation }\end{array}$ & $-.639^{* * *}$ & \\
\hline Sig. (2-tailed) & .000 & & \\
\hline $\mathrm{N}$ & 376 & 376 & \\
\hline
\end{tabular}

\footnotetext{
**. Correlation is significant at the 0.01 level (2-tailed). Source: Field Data (2020)
}

From the correlation analysis presented in Table 3, the relationship between the independent variable with the turnover intent was negative and strong. There was a significant strong inverse correlation between turnover intent and salary satisfaction $(r=-0.639, r<0.001)$. This therefore implies that increase in salary satisfaction will contribute substantially to the decrease in turnover intent among the teaching staff in public Universities in Kenya.

\subsection{Regression Analysis of the Relationship between Salary Satisfaction and Turnover Intentions among the Teaching Staff in public Universities in Kenya}

To establish the relationship between salary satisfaction and turnover intentions, a simple linear regression analysis was used. The regression model was of the form:

$$
Y=a+b X+\epsilon, \quad \epsilon \sim N(0,1)
$$

Where, $Y$ is the turnover intentions; $X$ is the salary satisfaction, $a$ is the constant of the regression equation, $b$ is the regression coefficient and $\epsilon$ is the error component.

The parameter estimates of the regression model are as shown in Table 4

Table 4: Regression Coefficients ${ }^{\mathrm{a}}$

\begin{tabular}{|c|c|c|c|c|c|c|}
\hline \multicolumn{2}{|c|}{ Model } & \multicolumn{2}{|c|}{$\begin{array}{c}\text { Unstandardized } \\
\text { Coefficients }\end{array}$} & $\begin{array}{c}\text { Standardize } \\
\mathrm{d} \\
\text { Coefficient } \\
\mathrm{s}\end{array}$ & $\mathrm{t}$ & Sig. \\
\hline \multicolumn{2}{|c|}{} & $\mathrm{B}$ & $\begin{array}{c}\text { Std. } \\
\text { Error }\end{array}$ & Beta & & \\
\hline \multirow{2}{*}{1} & $\begin{array}{c}\text { (Constant } \\
\text { ) }\end{array}$ & 19.064 & .299 & & 63.860 & .000 \\
\cline { 2 - 7 } & $\begin{array}{c}\text { Salary } \\
\text { Index }\end{array}$ & -.098 & .017 & -.313 & -5.963 & .000 \\
\hline
\end{tabular}

a. Dependent Variable: Turnover Intentions

Source: Field Data (2017)

The results presented in Table 4 shows a $t$-test value of -5.963 with a $p$-value of 0.000 which is less than the 0.05 level of significance. Therefore, the null hypothesis, 'Salary satisfaction has no statistically significant influence on turnover intentions among the teaching staff in public Universities in Kenya' is rejected.

The findings presented in Table 4 agree with Koitalek (2016) who concluded that remuneration was a significant predictor of turnover intentions among the employees at Teachers Service Commission in Kenya. Although, Koitalek (2016) supported the current study, the main limitation is related to the fact that the research was conducted among the employees working at Teachers Service Commission who were nonteaching staff.In this regard, the researchers found it difficult to generalize the results to the teaching staff in public Universities since they operate under different working environments. 


\section{CONCLUSIONS}

Based on the study findings, it was concluded that the teaching staff who are satisfied with their salary would have little intention to leave.

\section{RECOMMENDATIONS}

The study recommended that:

i. Public universities management to provide the satisfaction environment in terms of remuneration to manage future turnovers among the teaching staff.

ii. The government should consider re-looking at its salary scheme for the teaching staff in Public Universities in relation to other Countries. Failing to do so may have detrimental impact as dissatisfaction with salary can lead to higher turnover.

\section{REFERENCES}

[1] A'yuninnisa, R. N, \& Saptoto, R.(2015).The effects of pay satisfaction and affective commitment on turnover intention. International Journal of Research Studies in Psychology,2015 April, Volume 4 Number 2, 57-70

[2] Hasibuan, S. J., Mariatin, E \& Ananda, F.(2019). "The influence of Pay Satisfaction and Organizational Commitment on Turnover Intention on Employees of PT. Bank Muamalat Indonesia, Tbk Medan," International Research Journal of Advanced Engineeringand Science, Volume 4, Issue 3, pp. 96-98, 2019.

[3] Kratina, I., Zamfirescu, C.,Trepanier, K., \& Marques, L.(2015).Survey questionnaires and graphs. Electronic Journal of Statistics, 9(2), 2202- 2254.doi:10.1214/15- EJS1067

[4] Mabaso, C.M., \& Bongani, I. D. (2017). Impact of Compensation and Benefits on Job Satisfaction. Research Journal of Business Management, 11: 80-90.

[5] Park, T., \& Shaw, J. D. (2013). Turnover rates and organizational performance: A meta-analysis. Journal of Applied Psychology, 98(2), 268-309. http://dx.doi.org/10.1037/a0030723

[6] Spherion (2013). Emerging Workforce Study 2013. Online: http://www.spherion.com/ews - /survey findings/2013_ews/ [Accessed at 26 Jan. 2014]. Spherion Staffing LLC. 